DOI: 10.17117/na.2016.02.01.172

http://ucom.ru/doc/na.2016.02.01.172.pdf

Поступила (Received): 11.02.2016

\title{
Ильясова К.X.
}

\section{Повышение эффективности использование сельское и лесное хозяйство в Чеченской Республики}

\author{
llyasova K.Kh. \\ Improving the efficiency of use of agriculture and \\ forestry in the Chechen Republic
}

В разделе содержится информация о структурных изменениях в сельскохозяйственном производстве, развитии индивидуального сектора на селе, состоянии материально-технической базы сельского хозяйства, продукции растениеводства и животноводства, продовольственных ресурсах и их использовании и др. Данные приводятся в целом по сельскому хозяйству и по категориям сельскохозяйственных производителей. Представлены сведения по лесномухозяйству Ключевые слова: сельскохозяйственные организации, население, подсобные хозяйство, лесное хозяйство, лесной фонд

Ильясова Карина Хасайновна

Ассистент

Чеченский государственный университет г. Грозный
In a division there is information about structural changes in an agricultural production, development of individual sector on a mud flow, state of material and technical base of agriculture, products of plantgrower and stock-raising, food resources and their use of and other cited data on the whole on agriculture and on the categories of agricultural producers. Information is presented on forestry

Key words: agricultural organizations population, subsidiary economy, forestry, forest fund

\author{
Ilyasova Karina Husainovna \\ Assistant \\ Chechen state univercity \\ Grozny
}

В разделе содержится информация о структурных изменениях в сельскохозяйственном производстве, развитии индивидуального сектора на селе, состоянии материально-технической базы сельского хозяйства, продукции растениеводства и животноводства, продовольственных ресурсах и их использовании и др. Данные приводятся в целом по сельскому хозяйству и по категориям сельскохозяйственных производителей. Представлены сведения по лесному хозяйству.

По категории «сельскохозяйственные организации» показаны данные по производственным кооперативам, закрытым и открытым акционерным обществам, государственным предприятиям, обществам с ограниченной ответственностью, подсобным хозяйствам не сельскохозяйственных организаций.

К хозяйствам населения относятся личные подсобные и другие индивидуальные хозяйства граждан в сельских и городских поселениях, а также 
хозяйства граждан, имеющих земельные участки в садоводческих, огороднических и дачных некоммерческих объединениях граждан.

Личные подсобные хозяйства - форма непредпринимательской деятельности по производству и переработке сельскохозяйственной продукции, осуществляемой личным трудом гражданина и членов его семьи в целях удовлетворения личных потребностей на земельном участке, предоставленном или приобретенном для ведения личного подсобного хозяйства. Землепользование хозяйств может состоять из приусадебных и полевых участков.

Садоводческое, огородническое или дачное некоммерческое объединение граждан - некоммерческая организация, учрежденная гражданами на добровольных началах для содействия ее членам в решении общих социально - хозяйственных задач ведения садоводства, огородничества и дачного хозяйства.

Крестьянское (фермерское) хозяйство - объединение граждан, связанных родством и (или) свойством, имеющих в общей собственности имущество и совместно осуществляющих предпринимательскую, производственную и иную хозяйственную деятельность (производство, переработку, хранение, транспортировку и реализацию сельскохозяйственной продукции), основанную на их личном участии.

Индивидуальный предприниматель по сельскохозяйственной деятельности - гражданин (физическое лицо), занимающийся предпринимательской деятельностью без образования юридического лица, с момента его государственной регистрации в соответствии с Гражданским кодексом РФ и заявивший в Свидетельстве о государственной регистрации виды деятельности, отнесенные согласно Общероссийскому классификатору видов экономической деятельности (ОКВЭД) к сельскому хозяйству.

Продукция сельского хозяйства представляет собой сумму данных об объеме продукции растениеводства и животноводства всех сельхозпроизводителей, включая хозяйства индивидуального сектора (хозяйства населения, крестьянские (фермерские) хозяйства и индивидуальные предприниматели) в стоимостной оценке по фактически действовавшим ценам.

Продукция растениеводства включает стоимость сырых продуктов, полученных от урожая отчетного года - зерна, продукции технических культур (семян масличных культур, продукции сахарной свеклы, табака и махорки и др.), картофеля, овощей и бахчевых продовольственных культур, плодов и ягод, кормовых культур (кормовых корнеплодов, однолетних и многолетних сеяных трав, убранных на сено, зеленую массу и силос), семян и посадочного материала сельскохозяйственных культур и многолетних насаждений и изменение стоимости незавершенного производства в растениеводстве (посадка и выращивание до плодоношения сельскохозяйственных культур и многолетних насаждений) от начала к концу года и др.

Продукция животноводства включает стоимость сырых продуктов, полученных в результате выращивания и хозяйственного использования сельскохозяйственных животных и птицы (молока, шерсти, яиц и др.), стоимость реализованного скота и птицы, изменение стоимости выращивания молодняка и скота на откорме за год, стоимость продукции пчеловодства и др. 
Для исчисления индекса производства продукции сельского хозяйства используется показатель ее объема в сопоставимых ценах предыдущего года.

Индекс производства продукции сельского хозяйства - относительный показатель, характеризующий изменение массы произведенных продуктов растениеводства и животноводства в сравниваемых периодах.

Сельскохозяйственные угодья - земельные угодья, систематически используемые для получения сельскохозяйственной продукции. К ним относятся пашня, залежь, многолетние насаждения, сенокосы и пастбища.

Пашня - сельскохозяйственное угодье, систематически обрабатываемое и используемое под посевы сельскохозяйственных культур, включая посевы многолетних трав, а также чистые пары.

Посевные площади - часть пашни, занятая под посевы сельскохозяйственных культур.

Валовой сбор сельскохозяйственных культур включает в себя объем собранной продукции, как с основных, так и с повторных и междурядных посевов в сельскохозяйственных организациях, крестьянских (фермерских) хозяйствах, у индивидуальных предпринимателей и в хозяйствах населения.

Поголовье скота включает поголовье всех возрастных групп соответствующего вида скота.

Производство скота и птицы на убой - показатель, характеризующий результат использования скота и птицы для забоя на мясо. Общий объем производства скота и птицы на убой отражается в пересчете на убойный вес и включает как проданные скот и птицу, подлежащие забою, так и забитые в сельскохозяйственных организациях, крестьянских (фермерских) хозяйствах, у индивидуальных предпринимателей и в хозяйствах населения.

Производство молока характеризуется фактически надоенным коровьим, козьим, овечьим, кобыльим и буйволиным молоком, независимо от того, было ли оно реализовано или потреблено в хозяйстве на выпойку молодняка. Молоко, высосанное молодняком при подсосном его содержании, в продукцию не включается и не учитывается при определении средних удоев.

При расчете среднего годового надоя молока на одну корову в сельскохозяйственных организациях производство молока, полученного от коров молочного стада, делится на их среднее поголовье.

Производство шерсти включает весь объем фактически настриженной немытой шерсти, а также грубый волос коз и верблюдов. Шерсть, полученная с овчин при промышленной переработке их на кожу, в продукцию не включается.

Производство яиц включает их сбор за год от всех видов сельскохозяйственной птицы, в том числе яйца, пошедшие на воспроизводство птицы (инкубация и др.)

Информация о продовольственных ресурсах и их использовании формируется на базе данных форм федерального статистического наблюдения, данных обследования домашних хозяйств, таможенной статистики и других источников, характеризующих образование продовольственных ресурсов и направления их использования за календарный год. 
Лесной фонд - часть территории страны (субъекта Российской Федерации), занятая лесом, а также не занятая им, но предназначенная для нужд лесного хозяйства, включает: совокупность лесных земель и нелесных земель (занятых находящимися в лесах пашнями, сенокосами, пастбищами, водами, дорогами, просеками, усадьбами, болотами, песками и др.).

Лесные земли - земли, покрытые лесной растительностью (лесом), и земли, не покрытые лесной растительностью, но предназначенные для ее восстановления: несомкнувшиеся лесные культуры; лесные питомники и плантации; естественные редины; фонд лесовосстановления (гари, погибшие насаждения, вырубки, прогалины, пустыри).

Земли, покрытые лесной растительностью (лесом):

- земли, занятые лесными насаждениями естественного и искусственного происхождения с полнотой 0,4 и выше в возрасте молодняков и с полнотой 0,3 и выше в возрасте, превышающем возраст молодняков;

- земли, занятые кустарниками, на которых в силу естественно-географических условий не могут произрастать древесные породы или на которых специально организуются кустарниковые хозяйства (прутяных и высокотаннидных ив, орехоплодных, технических культур);

- плантации лесных древесных пород, предназначенные для ускоренного выращивания древостоев с целью получения целевых сортиментов или древесной массы для химической переработки (учитываются как лесные насаждения искусственного происхождения - лесные плантационные культуры).

Лесовосстановление - проведение мероприятий по восстановлению лесов на вырубках, гарях, пустырях, прогалинах и иных бывших под лесом площадях. Лесовосстановление осуществляется путем естественного, искусственного (создание лесных культур) или комбинированного восстановления лесов.

Искусственное лесовосстановление осуществляется путем посадки сеянцев, саженцев, черенков или посева семян лесных растений [3,стр 84].

\section{Список используемых источников:}

1. Асхабов Р.Ю. Пути повышения эффективности использования рабочей силы в сельском хозяйстве Дагестана и Чеченской Республики. Махачкала. 276 с.

2. Ильясова К.Х. Пути повышение эффективности использования земельных ресурсов Чеченской Республики-Грозный. 2014. 140 с.

3. Население Чеченстат // Официальная статистика. Население Содержание. Ростат в регионах.

(C) 2016, Ильясова К.X.

Повышение эффективности использование сельское и лесное хозяйство в Чеченской Республики (c) 2016, Ilyasova K.Kh.

Improving the efficiency of use of agriculture and forestry in the Chechen Republic 